\title{
Dijital Medya Okuryazarlığı: Sorunlar, Uygulamalar ve Beklentiler
}

\author{
Ali ÖzCAN, Gümüşhane Üniversitesi iletişim Fakültesi, Yrd. Doç.Dr., aliozcan@gumushane.edu.tr
}

$\ddot{O} z$

\begin{abstract}
Birkaç yıl öncesine kadar kitap/gazete/dergi okumak, televizyon/film izlemek, müzik dinlemek, video oyun oynamak için çeşitli araçlara gereksinim söz konusu iken günümüzde iletişim teknolojilerinde yaşanan gelişmelere bağh olarak tüm bu etkinliklere ayn anda tek bir cihaz sayesinde katılmak mümkündür. Bu yenilikler ve erişim kolaylı̆̆ medyayla bütünleşik bir yaşam tarzını mümkün kllmış, 'sanal âlem' toplumun kendisinin var olduğu gerçek bir mekâna dönüştürmüştür. Geleneksel medyada birer izleyici/okuyucu/dinleyici konumunda pasif roller alan birey, dijital medya ortamlarında katılımcl/üretici olarak pozisyonunu geliştirmiştir. Gelinen noktada, medyanın/aracın kendisi, tüketici/birey ve iletişim biçiminde yaşanan değişimlerin toplamı olarak dijital medya ortamları konusunda farkındalık düzeyi yüksek, eleştirel ve etkin bir şekilde kararlar alan sorumlu bireylerin yetişmesi büyük önem taşımaktadır. Bunun için geleneksel anlamda gazete, radyo ve televizyon gibi uygulanan medya okuryazarliğının dijital medya ortamlarına (internet, sosyal medya, mobil medya) uyarlanması gereklidir. Gelişen ve çeşitlenen dijital medya ortamlarında bireylerin etkin rol alması, araçlara ilişkin bilincin oluşması, içeriklerin doğru anlamlandırılması ve eleştirel bakış açısıyla yorumlanması en önemli konulardır. Basılı metinlerin okuryazarlığı topluma katılmak için bir ön koşul iken, günümüz yeni iletişim ortamlarında okuryazarlı yoğun enformasyon bombardımanına karşı eksiksiz ve doğru bilgilenmenin temel koşutu olmuştur. Bu çalışmada geleneksel medyadan dijital/yeni medyaya 'okuryazarlık' olgusunun dönüşümünün gerekliliği dijital medya okuryazarlığı uygulamaları üzerinden tartışılmıştır.
\end{abstract}

Anahtar Kelimeler: Medya Okuryazarlığı, Yeni İletişim Teknolojileri, Dijijtal Medya Okuryazarlığı

\section{Digital Media Literacy: Problems, Practices and Expectations}

\begin{abstract}
While having various tools was a necessity in order to read book /newspaper/magazine, to watch television/movie, to listen to music, and to play video games until a few years ago, it is now possible to join all these events simultaneously through just one device depending on developments in communication technologies. These innovations and accessibility make media integrated life style possible, and turn 'the virtual world' into real space in which society itself comes into being. Individual, who plays passive parts as viewer/reader/listener in traditional media, however improves his/her position as participant/producer in the new media. At this point, it is crucial to grow responsible people who has heightened awareness, who are critical and who are able to take decisions actively about issues on the new media, as total of changes in medium/instrument itself, consumer/individual and communication style. For this reason, the media literacy that has applied in tradition media such as newspaper, radio and television should
\end{abstract}


be integrated into the new media milieu such as internet, social network and mobile media. In developing and diversifying new media milieu taking active role of individuals, creating awareness regarding tools, making sense of contents and interpreting them in critical perspective are the most significant matters. While printed texts' literacy is prerequisite for fitting into society, literacy in the present-day new communication media has been basic condition of complete and accurate enlightenment against the intensive information bomb. In this study, the necessity of transformation of the phenomenon 'literacy' from traditional to the new media is discussed through the new media literacy applications.

Keywords: Media Literacy, New Communication Technology, Digital Media Literacy.

\section{Giriş̧}

Bilgi ve iletişim teknolojilerinin baş döndürücü bir şekilde çeşitlendirdiği günümüz iletişim ortamında başta sosyal medya uygulamaları olmak üzere dijital medya platformları, toplumu oluşturan bireylerin gündelik hayatlarının önemli bir bölümünde kendine yaygın bir kullanım alanı oluşturmuştur. Haber, eğlence ve reklam gibi geleneksel medya uygulamalarını analiz etmeyi ve eleştirel bir bakış açısıyla toplumu/bireyi medya ürünleri karşısında aktif bir şekilde konumlandırmayı amaçlayan medya okuryazarlığının, yeni iletişim teknolojileri ve dijital medya platformlarını da kapsayacak şekilde yeniden konumlandırılması gerekmektedir. Çünkü geleneksel medya ortamlarının bir eleştirisini sunan medya okuryazarlığının ürettiği söylem dijital medya formlarını olumlayan bir sürece dönüşmekte, geleneksele yönelik eleştiriler dijital medyayı değerli kılan bir algı üretmektedir. Bu algının temelinde, iletişim araçlarının çeşitlenmesi ve bireylerin iletişim araçlarına erişiminin mümkün olmasıyla düşünce ve ifade özgürlüğü arasında doğrudan bir bağın olması yatmaktadır. Ayrıca geleneksel medya ortamları karşısında izleyici/dinleyici/okuyucu konumunda olan bireyler, dijital medya formlarında artık aktif birer katılımcı/kullanıcı durumuna geçerek, medya içeriklerini tüketmenin yanında üretim boyutunun da en önemli bileşeni haline gelmiştir. $\mathrm{Bu}$ da geleneksel anlamda medya okuryazarlığının ötesinde dijital medya okuryazarlığ bağlamında birer içerik üreticisi olarak bireylerin nelere dikkat etmesi, ürettikleri içeriğin etkisi ve toplumsal hayatın üretimine/toplumsallaşma süreçlerine katkısını anlamayı, sorgulamayı gerektirmektedir. Kullanıcı olmak beraberinde bu iletişim araçlarını kullanmayı da gerektirmektedir. Çünkü dijital medya formları karşısında sadece pasif bir birey olarak bulunmamakta, aktif kullanıcısı konumunda olduğu için dijital medya platformlarının belli başlı özelliklerini bilmesi, içerik üretimi sırasında bunları tecrübe etmesi gerekmektedir. Ayrıca dijital medya ortamlarının günümüzde zorunluluktan öte gönüllülük/bağımlılık derecesinde kullanılıyor oluşu dijital medya okuryazarlığını zorunlu bir konuma taşımaktadır. Üstelik bu okuryazarlığın geleneksel medya okuryazarlığının ötesinde belli toplumsal kesimler (öğrenciler, ebeveynler) için değil herkese yönelik olması elzemdir. Çünkü içinde bulunduğumuz iletişim/bilgi çağında toplumu oluşturan her bir fert çeşitlenmiş medyanın bireyselleştirilmiş/kişiselleştirilmiş mesajlarının hedef kitlesi konumunda bulunmaktadır. Mobil iletişimin yaygınlaşması ve internetin sadece insanlar arası etkileşimi sağlayan araç olmaktan çıkıp nesneler arası iletişim (nesnelerin interneti) için kullanılması 
medyadan daha fazla bir zemini ifade eden (Uğur, 2013, s. X) yeni medya konusunda farkındalık oluşturulmasının ne kadar önemli olduğunu göstermektedir.

\section{Klasik Okuryazarlıktan Medya Okuryazarlığına: Kavramsal Bir Bakış}

Tarih boyunca farklı türlerde becerilere sahip olmayı ifade eden okuryazarlık kavramı, dumanı okuyan kızılderiliden halı desenini yorumlayan dokumacıya ve yazılı harfleri bilmekten bugün hayatımızı saran geleneksel ve yeni iletişim teknolojilerini kullanmaya kadar geniş bir yelpazede insan hayatına anlam katan en önemli husus olmuştur. Özellikle iletişim teknolojilerinde yaşanan gelişmeler sonucu daha karmaşık bir hal alan insan hayatında geleneksel anlamda ifade edilen okuma-yazma becerisinin yanında yeni okuryazarlık türlerinin de gerekliliği söz konusu olmuştur. İletişim araçlarının çeşitlenmesi ve insan hayatında kapladığı alanın genişlemesi doğal olarak günümüzde medyaya yönelik bir okuryazarlığı öncelikli forma dönüştürmüştür. 'Medyanın diliyle okuyup yazabilme becerisi' olarak tanımlanan medya okuryazarlığı, bireyin ihtiyaç duyduğu bilgiyi ilgili iletişim araçlarından elde edip çözümleyerek doğruluk ve güvenirlilik gibi konularda karara varmasına (cocukvemedyahareketi.org, 2013) imkân sunan beceriler bütünü şeklinde tanımlanmaktadır. Okuryazarlık olgusu yazıdan daha eski bir tarihe kadar gitse de bugün iletişim araçlarıyla özdeşleşir bir hal almıştır. İletişim araçlarının gelişimi doğrultusunda oluşumu gerçekleşen okuryazarlık olgusu medyadaki/iletişim araçlarındaki değişim/dönüşüm/yenileşme/çeşitlenmeyle eşdeğer olarak güncellenmektedir. Bugün ise ağırlıklı bir biçimde dijital medya ve özellikle de sosyal medya okuryazarlığı kavram haritasının içeriğini doldurmaktadır.

Tablo 1. Medya Okuryazarlığ1 Kavramının Tarihsel Süreçte Gelişimi

\begin{tabular}{|c|c|c|c|c|c|}
\hline Film & $\begin{array}{c}\text { Televizyon } \\
\text { Reklam }\end{array}$ & $\begin{array}{c}\text { Alternatif } \\
\text { Kitle İletişimi }\end{array}$ & $\begin{array}{l}\text { Televizyon } \\
\text { Düzenlemesi }\end{array}$ & $\begin{array}{c}\text { Dijital } \\
\text { Okuryazarlık }\end{array}$ & $\begin{array}{c}\text { Medya } \\
\text { Okuryazarlığı }\end{array}$ \\
\hline 1960-1970 & 1970-1980 & 1980 & 1980-1990 & 1990 & 2000 \\
\hline
\end{tabular}

Kaynak: Pérez-Tornero, J. M.,Celot, P., \& Varis, T. (2010). Study on the current trends and approaches to media literacy in Europe.

Yukarıda tabloda görüldüğü üzere iletişim araçları ekseninde okuryazarlık uygulaması ilk olarak filmler üzerinden başlatılmıştır. İletişim dünyasında yeni araçların ortaya çıkışı yeni okuryazarlık modellerini beraberinde getirmiştir. Tabloda da görüldüğü üzere 1990’lı yıllarda bilgisayar teknolojisinde yaşanan gelişmelerle eş değer olarak dijital okuryazarlık kavramı ön planda yerini almıştır. Bugün ise medya okuryazarlığı artık yeni bir aşamaya geçiş yapmıştır. $\mathrm{Bu}$ aşama 'yeni medya okuryazarlığı' ya da 'dijital medya okuryazarlığı' olarak ifade edilmektedir. Ancak iletişim teknolojilerinde yaşanan gelişmeler ve çeşitlenen iletişim araçları gerçeğini göz önünde bulundurduğumuzda şemsiye bir kavram olarak medya okuryazarlığ ifadesinin kullanımı yerinde olacaktır. 
1920 ve 1930'larda ABD ve Avrupa ülkelerinde kitle iletişimin (gazete/radyo/tv) ortaya çıkışıyla birlikte yayılan mesajların manipülatif kurgusuna karşı 'demokratik ve katılımcı bir bilinç yapısı oluşturmak’ (İnal, 2009, s. 15) için çeşitli çalışmalar yapılmıştır. Medya okuryazarlığı ile ilgili ilk sistematik tanımlama 1978 yılında Sirkka Minkkinen tarafından, bilişsel, etik, felsefi ve estetik boyutlarında becerilerin geliştirilmesini hedefleyen çalışma olmuştur (İnceoğlu, 2006, s. 5).

Günümüzde neredeyse artık her bir birey gündelik hayatında iletişim araçlarını gereksinim/zorunluluk yahut eğlence amaçlı olarak kullanmaktadır. Toplumsallaşmanın yanında bilgilenme ve iletişimin de bu araçlar üzerinden gerçekleşiyor oluşu medya konusunda yeterlilik geliştirmeyi gerekli kılmaktadır. Okuryazarlık olarak kavramsallaştırılan bu yeterlilik durumu, medya hakkında öğretme ve öğrenme sürecinin sonucunu ifade etmektedir. Bu durum medyayı hem okumak hem de yazmak olarak da ifade edilmektedir. Medya mesajlarının inşa edilmesinden, sanatsal ve ekonomik fonksiyonlarının idrak edilmesi kadar bir dizi anahtar kavram üzerinden (Hobbs, 2010, s. 88) gerçekleşen medya okuryazarlığı, hem eleştirel bakış açısıyla anlamak, hem de aktif katılım geliştirmeyi kapsamaktadır. Böylece medya tüketicilerinin eleştirel ve yaratıcı yetenekleri gelişmektir (Frau-Meigs, 2006, s. 20). Medya okuryazarlığ1 yoğun olarak eleştirel düşünce etrafında şekillenmektedir. Ancak eleştirel çözümleme sürecinin yanında kişinin basılı, işitsel, görsel mesajlarını yaratmayı öğrenmesi (Hobbs, 2004, s. 122) gerçek anlamda bir medya okuryazarlığı sürecini tanımlamaktadır. Bu söylemlerin ışığında bir üst tanımlama olarak "Yazılı, görsel, işitsel gibi çeşitli biçimlerdeki medya iletilerine erişme, erişilen metinleri anlama, çözümleme, değerlendirme ile kendi iletisini ve medyasını üretebilme becerisi" (www.cocukvemedyahareketi.org, 2013, s. 19) medya okuryazarlığını ifade etmektedir.

Tarihsel süreçte medya mesajlarına karşı okuryazarlık olgusu savunmacı bir girişim olarak başlamıştır. Temel amacın zararlı mesajlardan korunmak olduğu bu okuryazarlık yaygınlaştıkça bireyi cesaretlendirici bir yaklaşıma doğru ilerlemiştir. Korunmacı boyutta başlayan okuryazarlık, eleştirel anlama, analiz etme ve medya mesajı üretmeye varan bir eğilimle bugüne gelmiştir. Bu sürecin dijital medya ortamları için de geçerliliği söz konusudur. Örneğin, internet ilk ortaya çıktığında öncelikle korunmacı bir yaklaşım sergilenmiştir (FrauMeigs, 2006, s. 23). İçinde bulunduğumuz zaman diliminde ise korunmacı yaklaşım yerini farklı ortamlardaki medya mesajlarına ulaşma, bunları analiz edip anlama, değerlendirip kendi medya mesajını üretme (Taylor, 2002, aktaran Çakmak, 2010, s. 11) şeklinde güncel bir bakış açısına bırakmıştır.

\section{Türkiye'de Medya Okuryazarlığı Uygulamaları}

Türkiye'de kamusal anlamda 2000'li yılların ardından tartışılmaya başlanan medya okuryazarlığı olgusu, özellikle de çocuk ve gençlerin medya tarafından üretilen mesajları maruz kalmasının getirmiş olduğu olumsuz sonuçlar dolayısıyla Milli Eğitim Bakanlığı tarafından önce pilot illerde sonra da tüm ülke genelinde seçmeli 'medya okuryazarlığı' dersi uygulamasıyla başlamıştır. Küreselleşmeyle birlikte değişen aile yapısı ve çocukların da 
toplumsallaşmasının medya üzerinden gerçekleşiyor oluşu nedeniyle medya okuryazarlığ eleştirel bir gözle medyanın etkilerinden korunma üzerine inşa etmeye yönelik bir eğitim olmuştur (Pembecioğlu, 2013, s. 408). Bu korunmacı yaklaşımın medya okuryazarlığının bütünsel uygulaması olmadığı yukarıda yapılan tanımlamalardan ortaya çıkmaktadır. Çünkü medya okuryazarlığ 1 korunmacı bir yaklaşımdan öte medya mesajlarına karşı bir duruşu ifade etmekte, edilgen bireyi etken/etkili bir konuma taşımayı amaçlamaktadır. Son dönemde Milli Eğitim Bakanlığı çocuklara yönelik medya okuryazarlığı programında geleneksel medyanın yanı sıra sosyal ağlar ve video oyunlar gibi dijital ortamlardaki içeriklere ulaşıp çözümlemenin yanında kendi içeriklerini üretmeyi amaçlamaktadır (MEB, 2013, s. 3). Bu amacın uygulamada (medya okuryazarlığı derslerinde) ne kadar gerçekleştirildiği ayrı bir çalışma konusunu teşkil ederken, burada medya okuryazarlığının ruhuna uygun bir anlayışın olduğunu söylemek mümkün olacaktır.

Medya okuryazarlığı konusunda dünyanın çoğu ülkesinde olduğu gibi Türkiye' de de temel amaç, medya ve içerikleri konusunda bireylerde bir bilinç oluşturmak ve bunu geliştirmek için sorgulayıcı bir bakış açısı geliştirmek ve böylece alt metinleri anlamlandıracak bir eğitim vermektir. Metin analizi, içerik analizi, örnek vaka incelemesi gibi sorgulayıcı bir bakış açısının geliştirilmesiyle başlayan medya okuryazarlığı eğitimi sayesinde bireylerin şu kazanımları elde etmesi öngörülmektedir:

- Medyanin hayatındaki yerini kavrar.

- Medya tüketim alışkanlıklarımı değerlendirir.

- Eğlence amacı ile seçilen medya iletilerinin içerik ve biçim özelliklerini çözümler.

- Bilgiye ulaşmak için farklı medya araçların ve arama stratejilerini kullanır.

- Medyanın bilgi kaynă̆ı olarak gücünü kavrar.

- Tüm medya iletilerinin kurgulanmış olduğunu kavrar.

- Doğruluğu konusunda değerlendirmeler yapabilmek için medya iletilerini çözümler.

- Medya iletilerinin doğruluğunu farklı kaynaklarla karşılaştırarak değerlendirir.

- İkna etme amacıyla medya iletilerinin nasıl kullanıldı̆̆ııı kavrar.

- Iikna tekniklerini göz önüne alarak içerikleri çözümler.

- Yeni medyanın bireye sunduğu imkânların farkına varır. (MEB, 2013, s. 6-7).

Medya okuryazarlığı ile elde edilecek kazanımlar arasında dijital medya platformlarına karşı bir farkındalığın da olduğu görülmektedir. Çünkü artık dijital medya platformları da birey ve toplum hayatının önemli bir kısmını (geleneksel medyadan daha üst düzeyde bir kullanım alanı) teşkil etmektedir. Birey ve toplumun dijital medyayı kullanma, yorumlama, paylaşma, işbirliği yapma, eleştirel olarak değerlendirme ve dijital medya içeriği oluşturmak için gerekli becerilerin sunumu (Balaban-Salı, 2012, s. 292) olarak tanımlanan dijital medya okuryazarlı̆̆ birey ve toplum hayatındaki önemiyle doğru orantılı bir şekilde çalışmalara konu olmaktadır.

\section{Dijital Medya Okuryazarlığı}

Genel olarak teknolojik ve özelde ise bilgi ve iletişim teknolojilerinde yaşanan gelişmeler sonucunda medya geleneksel ve yeni/dijital olmak üzere iki boyutlu bir aşama geçiş yapmıştır. 
Bir yanda yazılı ve analog yayınlar (geleneksel medya) diğer yanda çevrimiçi ve dijital yayınlar (yeni/dijital medya) söz konusu olmuştur. Dönüşüm sadece iletişim araçlarında olmamış bireyler de geleneksel medyanın okuyucu/dinleyici/izleyici konumundan yeni medyanın kullanıcı boyutuna taşınmıştır. Özellikle de sosyal paylaşım siteleriyle birlikte Web 2.0 ortaminda enformasyonun takip edeni olmaktan üreteni boyutuna gelinmesiyle birlikte katılımcı bir kültürün ortaya çıkışı dijital medya ortamlarının en temel belirleyeni olmuştur. Ayrıca dijital medya ortamlarının otokrasiye karşı demokrasi, gözetlemeye karşı özgürlük, tekelleşmeye karşı çoğulculuk alternatiflerini mümkün hale getirmesi, beraberinde dijital medya okuryazarlığı kavramını birey ve toplum hayatına sunmuştur.

Bilgi dünyasının Big Bang'i (büyük patlama) olarak tanımlanan internet (Hansen ve Paul, 2004, Aktaran Çakmak, 2010, s. 2) ve bu patlamanın ortaya çıkardığı dijital medya uygulamaları olarak sosyal platformlar artık okuryazarlık olgusunun yazılı, görsel, işitsel olmaktan öteye geçip bambaşka bir dünyaya (sanal uzam) geçişin olduğunu göstermektedir. Bu durum medya okuryazarlığı altında yeni bir başlık olarak dijital medya okuryazarlığı ve bunun da alt başlıklarından sosyal medya okuryazarlığı kavramını (Durak \& Seferoğlu, 2016, s. 527) toplum hayatına sunmuştur. Dijital medya platformlarının çeşitlenmesi, geleneksel medya uygulamalarının da dijital medyayla entegre bir yapı inşa etmeye çalışmasıyla birlikte dijital medya okuryazarlığı daha baskın bir durum arz etmeye başlamıştır. Bu durum bize medya okuryazarlığı olgusunun içeriğinin güncellenmesinin ne kadar önemli olduğunu göstermektedir.

Dijital medya ortamları, ifade özgürlüğü ve demokratik katılımı güçlendirip yaygınlaştırmasının yanında gözetim/denetim, sansür gibi riskleri de bünyesinde barındırmaktadır. Dijital medya ortamlarının 'kendinde' olmayan bu risk ve fırsatları ona verecek olan kullanıcıların iradesidir. Dijital medya okuryazarlığ sergilenmesinde en önemli göstergelerden biridir (Özçetin, 2015, s. 2). Çünkü demokratik ortamın öznesi olarak üreten, paylaşan ve tartışan bireyler için yeni medya ortamları kamusal alan imkânı sunmakta ve bu alanın doğru, bilinçli ve hukuki bir şekilde kullanılabilmesi için dijital medya okuryazarlığı büyük öneme haizdir. Dijital medya okuryazarı olma becerisini kazanan bireylerin mahremiyet, ifade özgürlüğü, internet hukuku, bilgi üretimi ve yönetimi başta olmak üzere kendinde müstakil becerilerin yanı sıra dijital medya ortamlarının sahiplik yapısı, dijital medyanın dili ve kavramları konusunda da temel bilgilere sahip olması gerekmektedir (Arslan, 2015, s. 42-43). Bu iki yönlü beceri dijital medya platformlarını daha doğru bir şekilde kullanma bilincini sağlayacaktır.

Medya okuryazarlığının güncel bir kavramsallaştırması olarak dijital medya okuryazarlığı konusunda yapılan çalışmalar iletişim teknolojilerindeki gelişmeler, yeni iletişim araçlarının bireyin kişisel ve toplumsal hayatının büyük bir bölümünde kapsayıcı bir rol üstlenmesiyle ortaya çıkmıştır. Avrupa Birliği tarafından 2000' de Libzon'da gerçekleştirilen zirvede bilgi ve iletişim teknolojileri ile bilgi toplumu arasındaki bağ beraberinde sunduğu fırsatlar ve tehditler boyutuyla tartışılmış, medya okuryazarlığının önemine binaen yeni medya ortamları için de becerilerin geliştirilmesi yönünde dijital/yeni medya okuryazarlığı kavramına vurgu 
yapılmıştır. Ayrıca Avrupa Komisyonu, 2009'da medya okuryazarlığının kapsamının yeni medya ortamlarını da içine alacak şekilde genişletilmesi yönünde tavsiye karara imza atmıştır (Hasdemir, 2012, s. 28). Dijital medya okuryazarlığını konu alan çalışmalar incelendiğinde geleneksel medya okuryazarlığı ile ilişkili çalışmalardan etkilendiği/türetildiği görülecektir. Devam eden süreçte ise dijital medyayı geleneksel medyadan ayıran karakteristik özellikler (etkileşim, katılım) üzerinden dijital medya okuryazarlığı konusunda özgün çalışmalar elde edilmiştir.

İçeriğin, kullanıcıların ve katılımcılığın değiştiği dijital medyada, okuryazarlık geleneksel medyada olduğu gibi yalnızca içeriğe anlam vermekle sınırlı kalmamakta, içeriğin oluşturulması eyleminde de kendini göstermektedir. Dijital medya okuryazarlığı olgusunu geleneksel medyadan ayıran en başat farklılık da içerik üretimine ilişkin sunmuş olduğu imkânlardır (Solmaz, 2016, s. 9). Yeni medyanın sunmuş olduğu katılımcılık ve interaktifliğin bir sonucu olarak gerçekleşen içerik üretiminin bu denli yaygınlaşması enformasyonun giderek artmasına ve bu durumun doğal bir sonucu olarak dezenformasyon, enformasyon obezitesi gibi sorunlara neden olmaktadır. İçinde bulunduğumuz dijital medya çağında bu sorunlar sıkça yaşanmakta ve çözümüne dönük her bir adım dijital medya okuryazarlığına katkı sunmaktadır. Dijital medyanın sunmuş olduğu avantajların yanında bu meydan okumalar karşısında bir duruş sergilemek etik ve ahlak ilkelerinin belirlenmesine giden bir süreci doğurmaktadır. Dijital medya ortamlarında bilinmesi ve uyulması gereken ilkeler olarak etik ve ahlak kuralları aynı zamanda temel bir okuryazarlık bilgi birikimini sunmaktadır.

Dijital medya tanımlamalarının zihinlerde oluşturduğu algı olumlu bir bakış açısını sunmaktadır. Çünkü dijital medya tanımlamaları daha çok geleneksel medya üzerinden yapılmakta, geleneksel medyanın eksiklikleri ya da açmazlarının dijital medya ile birlikte bertaraf edildiği sık sık yinelenmektedir. Belli bir merkeze bağlı olmayan ağ üzerinde gerçekleşen dijital medya uygulamaları geleneksel medyaya has olan bir merkezden yönetilme sorunsalını ortadan kaldırmış gözükmektedir. Geleneksel medyaya göre daha yatay bir iletişim imkânı sunan dijital medya formlarının daha demokratik ve katılımcı bir yapı sergilediği anlatılmaktadır (Dijk, 2016, s. 156-157) Bu sayede herkesin bir yayıncı olma imkânına sahip olduğu ve özgürlük ortamı sunduğu sık sık dile getirilmektedir.

Dijital medyaya ilişkin, geleneksel medyanın açmazları/sınırlılıkları/eksiklikleri üzerinden getirilen tanımlamalar kendi bağlamında doğru bir yorum olarak görülse de dijital medya, ortadan kaldırdığı problemlerin daha fazlasını beraberinde getirmektedir. Bunların başında, gözetim ve mahremiyetin dönüşmesi, kullanıcının emeğinin sömürülmesi olarak ifade bulan üre-tüketici (üreten tüketici / prosumer) olgusunu getirmiştir (Fuchs, 2015, s. 157, Fuchs, 2016, s. 51-52) Dijital medyaya bu kisitlamaları da beraberinde getiren özellikler üzerinden baktığımızda tam anlamıyla bir medya okuması yapılmış olunacaktır.

Hayatın sürekli kendini yenilediği, kurumların ve kuruluşların dönüşerek yeni yapılar haline geldiği ve bu dönüşümün hep olumlu/artıları üzerinden değerlendirilmeye tutulduğu günümüz iletişim ortamı problemli bir algının varlığını göstermektedir. 
Medya mesajlarının doğru algılanması (İnceoğlu, 2006, s. 4) olarak ifade bulan medya okuryazarlığı günümüz iletişim ortamında büyük önem taşımakta ve hayatımızın her alanını kapsayan dijital medya uygulamalarının varlığı bu önemin giderek arttığını ortaya koymaktadır. Çünkü bilgi ve iletişim teknolojilerinde yaşanan baş döndürücü gelişmeler medya kullanım biçimlerini dönüştürmüş, geçmişte izleyici/dinleyici/okuyucu olan kişiler bu dijital medya ortamında birer kullanıcı haline gelmiştir. Yeni iletişim teknolojileriyle değişen iletişimin doğasına uyum sağlamak (Hobbs, 2010, s. 89) büyük önem arz etmektedir.

Öte yandan iletişim teknolojilerindeki dönüşüm ve yenilikler beraberinde yaygınlaşmasını sağlamıştır. Hızlı bir şekilde yaygınlaşan iletişim teknolojilerinin özellikle genç kuşak olarak çocuk ve gençlerin hayatında kullanım alanı genişlemektedir. Gençlik ve Spor Bakanlı̆̆ı'nın 'Gençlik ve Sosyal Medya' başlıklı araştırma raporu bu durumu doğrulamaktadır. Rapora göre, sosyal medyaya bağlanan araçların çeşitlenmesi (masaüstü, dizüstü bilgisayar ve mobil/akıllı telefonlar) ağ üzerinde geçirilen zamanın da artışını beraberinde getirmektedir. Rapora göre, gençlerin üçte biri günde en az üç saatini sosyal medyada geçirmektedir (İpsos, 2013, s. 134). We Are Social'in hazırlamış olduğu 2017 yılı raporu da aynı yönde verileri sunmaktadır. Rapor, dünya genelinde dijital, sosyal ve mobil medyanın durumunu gözler önüne sererken, Türkiye'yi de diğer ülkelerle karşılaştırma imkânını sunmaktadır. Rapora göre, 80 milyonluk Türkiye' de 46 milyonu yani yüzde 60'lık kesim internete bağlanmaktadır. Türkiye'de aktif sosyal medya hesabı bulunan kullanıcı sayısı ise 48 milyona ulaşmıştır (www.wearesocial.net, 2017). Bu durumun doğal bir sonucu olarak çevrimiçi iletişimin pratikleri üzerine yapılan çalışmalar da son dönemde artış göstermiştir. Ancak bu sürece ilişkin eleştirel bir analizi gerekli kılan dijital medya okuryazarlığı bağlamında çalışmalar sınırlı kalmaktadır. Yukarıda yer alan rakamlar topluca değerlendirildiğinde çocuk ve gençlerin önemli bir bölümünün çevrimiçi dünyada var oldukları net bir şekilde ifade edilebilir. Özellikle çocukların dijital medya uygulamaları karşısında pasif bir üreten tüketici olarak kalmak yerine, dijital medya okuryazarı olarak belli becerilere sahip olması gerekmektedir.

Dijital medya teknolojileriyle birey ve toplum hayatının bir yansıması olarak sosyal bilimlerde medya literatürüne giren 'dijital uçurum' un da kapanması dijital medya okuryazarlığı ile mümkün olmaktadır (Türkoğlu, 2013, s. 139). Çünkü dijital uçurumu kapatmanın bir ayağ1 iletişim teknolojilerine erişimi, bir diğer ayağı da erişilen bu iletişim teknolojilerinin kullanımı konusunda yüksek dijital beceriye sahip olmayı gerekli kılmaktadır (Dijk, 2016, s. 184)

Dijital medya teknolojilerinin demokratikleştirici, katılımcı ve özgürlükçü ruhunun korunması için de dijital medya okuryazarlığı bir zorunluluk arz etmektedir. Yeni iletişim teknolojilerinin eleştirisi olarak okuryazarlık bu teknolojilerin doğru bir amaç etrafında kullanılmasını sağlayacaktır. Kellner de $(2004,723)$ dijital teknolojilerin insan ve toplum hayatında yaygınlık kazandığını ve bunun bir sonucu olarak dijital medya teknolojilerine yönelik okuryazarlığın bir ihtiyaç olduğunu vurgulamaktadır. Dijital medya teknolojilerinin

\footnotetext{
${ }^{1}$ Toplumun ya da bireylerin iletişim teknolojilerine ulaşma ve kullanma imkanı konusunda farklılıkların ülkeden ülkeye, ya da bireylerden bireylere farklılık arz etmesi.
} 
meydan okumasına karşı yeni okuryazarlıklar geliştirmenin hayati önemde olduğunu da vurgulayan Kellner (2014, s. 414), 'enformasyon ve çoklu medya okuryazarlığı' olarak kavramsallaştırdığ bu olgunun yeni çoklu medya ortamında her zamankinden daha önemli olduğunu ifade etmektedir. Kellner (1995, s. 335), insanın tıpkı yedikleri gibi görüp işittiklerinden ibaret olduğu şeklinde bir kavramsallaştırma yaparak, tıpkı sağlıksız besinlerden (junk food) kaçınarak daha besleyici yiyecekler tercih etmek gibi insanların iletişim araçlarının kültüründen kaçınma konusunda duyarlı olmaları gerektiğini vurgulamaktadır. Kellner, çözümün iyi ile kötü ürünler arasındaki ayrımı öğrenmekten geçtiğine işaret ederek, günümüz iletişim ortamını ifade eden dijital medya okuryazarlığının ne kadar gerekli olduğuna bizleri yönlendirmektedir. Dijital medya okuryazarlığı geleneksel anlamda medya okuryazarlığının güncellenmiş bir formu olarak yeni iletişim ortamlarının kullanımı konusunda bilgi ve beceriyi gerektirmenin yanında üre-tüketicilerin (prosumer) farkındalığını geliştirmeyi amaçlamaktadır. Bütün bu değerlendirmelerden hareketle özellikle sosyal medya platformları üzerinden tanımlanan dijital medya konusunda okuryazarlık, geleneksel medya araçları için geçerli olan medya mesajlarını bilinçli, eleştirel ve analitik okuyup tüketme ve anlamlandırmayla sınırlı kalmamaktadır. Tüketici olmanın yanında dijital medya formlarının içeriklerinin birer üreticisi olan bireylerin kullanıcı olarak etkin dijital medya yönetimi ve nitelikli içerik üretmenin gerektirdiği altyapıya da sahip olması şarttır.

Öte yandan iletişim teknolojilerindeki gelişmeler de dijital medya okuryazarlığı olgusunun sürekli güncellenmesi gerçeğini ortaya çıkarmaktadır. Bu durumun en somut göstergesi mobil iletişim teknolojilerindeki gelişmelerdir. Türkiye'nin mobil iletişim kullanıcı sayısının 2016 yılında 36 milyonken (wearesocial.com, 2016), 2017 yılında bu sayının 42 milyona (wearesocial.com, 2017) çıkmış olması gelişme hızını gözler önüne sermektedir. Mobil iletişimin yaygınlaşması beraberinde mobil iletişim olgusunun da medya okuryazarlığı bağlamına dahil edilmesini gerekli kılmıştır. Mobiliteyle birlikte zaman ve uzama olan bağımlığın ortadan kalkması dijital medya okuryazarlığına yeni bir eksen/alan oluşturmuştur.

\section{SONUC}

Okuryazarlık olgusu klasik anlamda okuryazarlıktan (okuma-yazma ve anlama), görsel-işitsel okuryazarlığa ve dijital/yeni medya okuryazarlığına doğru bir gelişme göstermiştir. Bilişim ve enformasyon teknolojilerindeki sıra dışı gelişmelerin sonucu olarak nicelik açısından artışın yaşandığı iletişim araç ve kanalları, bireyin günlük kişisel ve toplumsal hayatını sosyal, ekonomik, siyasal ve kültürel olmak üzere ürettiği yeni bir zaman/uzam sunmaktadır. Gerçek hayatla siber uzamın bu denli iç içe girmesi beraberinde önemli sorunları ortaya çıkarmaktadır. Etik/ahlak kurallarının çiğnenmesinden, bireyin hem zihinsel hem de emek yoğun olarak köleleştirilmesine kadar geçmişten bugüne ortaya çıkan medya kaynaklı sorunlarla birlikte yeni sorun ve problemlerin ortaya çıkışı medya karşısında bireyi/toplumu çaresiz bırakmaktadır. Medya mesajlarına karşı bir duruş olarak ortaya çıkan 'okuryazarlık' kavramı bireyi araçlara/mesajlara karşı edilgen yapıdan proaktif bir konuma yükseltmektedir. Medyadaki dönüşüm ve yeni gelişmelere ayak uydurabilmek için tüketicilerin de sadece medya okuryazarı değil aynı zamanda dijital medya okuryazarı olmaları gerekmektedir. Hatta iletişim teknolojilerinin güncellediği iletişim ortamlarına karşı tüketicilerin de kendilerini sürekli güncellemeleri gerekmektedir. Akgül'ün (2015, s. XIV) deyimiyle 
medyadaki dönüşüm sürecine eş değer olarak okuryazarlığın da yeni iletişim teknolojileri üzerinden güncellenmesi büyük önem arz etmektedir.

Günümüzde dijital medya okuryazarlığı bir vatandaş olarak topluma katılımda önemli bir rol oynar hale gelmiştir. Kellner'in de 'insan ne görür ve işitirse odur' ifadesinden hareket ederek insanların medya üzerinden bilgilenmeleri konusunda sağlıklı bir yapının inşa edilmesi doğal olarak yeni iletişim teknolojilerinin hakim olduğu günümüzde dijiital medya okuryazarlığını zorunlu kılmaktadır. Dijital medya teknolojilerinin hızlı gelişimi ve hayatın her alalında kendine yer edinmesi, özellikle gençlerin zamanının önemli bir bölümünü dijital medya platformlarında geçiriyor oluşu dijital medya okuryazarlığını bir zorunluluk haline getirmektedir. Sadece sosyal hayatın değil ekonomik, siyasal ve kültürel hayatın da dijital medya aracılı bir şekilde üretiliyor oluşu, okuryazarlık becerisinin önemini bir kat daha artırmaktadir.

\section{KAYNAKÇA}

Akgül, M. (2015). İnternet, Yeni Medya ve Özgürlükler. Yeni Medya Çalışmaları (s. XIV). İstanbul: Alternatif Bilişim Derneği.

Arslan, Y. M. (2015). Kadınların Yeni Medya Okuryazarlığına İlişkin Bir Araştırma. Yeni Medya Çalışmaları (s. 42-53). İstanbul: Alternatif Bilişim Derneği.

Aslıhan Ardıç Çobaner, B. G. (2016). Yeni Medya Okuryazarlığını Anlamak: Sosyo-Kültürel Bir Çerçeve. Türkiye'de Internet Konferansı. Ankara: İnternet Teknolojileri Derneği. Nisan 20, 2017 tarihinde http://inet-tr.org.tr/inetconf21/bildiri/20.pdf adresinden alındı

Balaban-Salı, J. (2012). Yeni Medya Okuryazarlığı. D. Yengin içinde, Yeni Medya ve... (s. 291-310). İstanbul: Anahtar Kitaplar.

Barut, E., \& Koç, M. (2016). Yeni Medya Okuryazarlığı. A. İşman, H. F. Odabaşı, \& B. Akkoyunlu içinde, Eğitim Teknolojileri Okumaları 2016 (s. 595-613). Ankara: TOJET.

cocukvemedyahareketi.org. (2013). Çocuk ve Medya Hareketi Büyük El Kitabı. Nisan 19, 2017 tarihinde http://www.cocukvemedyahareketi.org: http://www.cocukvemedyahareketi.org/Files/pdf/cocuk-ve-medyahareketi/Cocuk_ve_Medya_Hareketi_Buyuk_El_Kitabi_Yetiskinler_icin.pdf adresinden alındı

Çakmak, E. (2010). Ingiltere ve Türkiye'deki Illköğretim Medya Okuryazarlığı Eğitimi Program ve Uygulamalarının Karşılaştırmalı Olarak Incelenmesi . Bolu: Abant İzzet Baysal Üniversitesi / Sosyal Bilimler Enstitüsü / Eğitim Bilimleri Bölümü / Eğitim Bilimleri Anabilim Dalı / Eğitim Programları ve Öğretim Bilim Dalı Yayınlanmamış Doktora Tezi.

Dijk, J. V. (2016). Ağ Toplumu (3. Baskı). (Ö. Sakin, Çev.) İstanbul: Kafka-Epsilon Yayıncılık.

Durak, H., \& Seferoğlu, S. S. (2016). Türkiye'de Sosyal Medya Okuryazarlığı ve Sosyal Ağ Kullanım Örüntüleri. Uluslararası Sosyal Araştırmalar Dergisi, 9(46), 526-535.

Frau-Meigs, D. (2006). Medya Eğitimi. Paris: UNESCO. 
Fuchs, C. (2015). Dijital Emek ve Karl Marx. (T. E. Kalaycı, \& S. Oğuz, Çev.) Ankara: Notabene Yayınları.

Fuchs, C. (2016). Sosyal Medya: Eleştirel Bir Giriş. (i. Kalaycı, \& D. Saraçoğlu, Çev.) Ankara: NotaBene Yayınları.

Hasdemir, T. A. (2012). Gelenekselden Yeni Medya Okuryazarlığına: Türkiye Örneğinde Bir Değerlendirme. Hitit Üniversitesi Sosyal Bilimler Enstitüsü Dergisi, 5(2), 23-40.

Hasdemir, T. A. (2013). MOY'dan Bit'e: Eğitim Serüveninin Neresindeyiz? Yeni Medya Çalışmaları (s. 414-429). Kocaeli: Alternatif Bilişim Derneği.

Hobbs, R. (2004). Medya Okuryazarlığı Hareketinde Yedi Büyük Tartışma. Ankara Üniversitesi Eğitim Bilimleri Fakültesi Dergisi, 37(1), s. 122-140.

Hobbs, R. (2010). Dijital Çağda Medya Okuryazarlı̆ı̆ı Yeniden Tanımlamak. (F. Yıldız, Dü.) Akademia, 87-95.

https://wearesocial.com/blog/2017/01/digital-in-2017-global-overview

İnceoğlu, Y. (2006). Medyayı Doğru Okumak. Medya Okuryazarlığı (s. 4-8). İstanbul: Marmara Üniversitesi Illetişim Fakültesi.

İpsos. (2013). Gençlik ve Sosyal Medya Araştırma Raporu. Ankara: Gençlik ve Spor Bakanlığı.

Kellner, D. (1995). Media Culture. New York : Routledge.

Kellner, D. (2004). Tabandan Küreselleşme: Radikal Demokratik Bir Teknopolitikaya Doğru. M. Özbek içinde, Kamusal Alan (s. 715-735). İstanbul: Hill Yayınları.

Kellner, D. (2014). Yeni Medya ve Yeni Okuryazarlık: Yeni Binyılda Eğitimin Yeniden Yapılandırılması. M. Çakır içinde, Yeni Medyaya Eleştirel Yaklaşımlar (M. A. Barış, Çev., s. 411-442). İstanbul: Doğu Kitabevi.

MEB. (2013). Ortaokul ve Imam Hatip Ortaokulu Medya Okuryazarlığı Dersi Öğretim Programı. medyaokuryazarlıgı.gov.tr: http://www.medyaokuryazarligi.gov.tr/lib_yayin/73AOB121181C-4F80-A6B9-B37E255ED03A.pdf adresinden alındı

Özçetin, B. (2015). Yeni Medya Okuryazarlığı ve Katılımcı Yurttaşlık: Sorunlar, Paradigmalar ve Uygulamalar. Yeni Medya Çalışmaları (s. 2). İstanbul: Alternatif Bilişim Derneği.

Pembecioğlu, N. (2013). Gelecek Kurguları ve Medya Algıları. 1. Türkiye Çocuk ve Medya Kongresi (s. 397-429). İstanbul: Çocuk Vakfı Yayınları.

PÉREZ-Tornero, J. M., Celot, P.,\&Varis, T. (2010).Study on the current trends and approaches to media literacy in Europe. Brussels: European Commission.

http://ec.europa.eu/culture/library/studies/literacy-trends-report_en.pdf,

Solmaz, T. (2016). Yeni Iletişim Teknolojileri Bağlamında Medya Okuryazarlığı . Erzurum: Atatürk Üniversitesi / Sosyal Bilimler Enstitüsü / Radyo Televizyon ve Sinema Anabilim Dalı / Radyo Sinema ve Televizyon Bilim Dalı Yayınlanmamış Yüksek Lisans Tezi.

Türkoğlu, T. (2013). Dijital Tefekkür. İstanbul: Beyaz Yayınları. 
Uğur, A. (2013). CeheNNet Vaadi Yeni Medya. Yeni Medya Çalışmaları (s. X). Kocaeli: Alternatif Bilişim Derneği.

www.cocukvemedyahareketi.org. (2013). I. Türkiye Çocuk ve Medya Stratejisi ve Uygulama Planı 2014-2018. Nisan 20, 2017 tarihinde Çocuk ve Medya Hareketi:

http://www.cocukvemedyahareketi.org/Files/pdf/kongre_yayinlari/Strateji_Kitabi_kongre_s onrasi_1.pdf adresinden alındı 